The Geneva Papers on Risk and Insurance, 23 (No. 88, July 1998) 364-371

\title{
ACKNOWLEDGEMENTS The Twenty-fifth Birthday of The Geneva Association
}

\author{
by Fabio Padoa*
}

Ideas are much like the children it is given to us to bear. Where are they coming from? What shall their future be? It all started, of course, with an idea-shared by a closed circle of friends - that the scientific credibility of insurance could no longer be left to the sole expertise of lawyers and actuaries, and that it deserved, by reason of the importance and special structure it had by then acquired, the specific attention of economists. But none of us anticipated that the Geneva Association, which was founded shortly afterwards to give practical expression to this idea, was soon to become a world centre for reflection on the problems of risk and on the role of insurance in contemporary society.

The idea had certainly come to us at the right moment. However, for the authoritative implementation of that idea credit must go to Raymond Barre, the Association's first President, and to the distinguished personalities who succeeded him, but it must also, and perhaps above all, go to Orio Giarini, the Association's Secretary General, for the imagination, the consistency of purpose and the untiring commitment he has displayed.

In the economy overall, insurance functions both as an economical tool for the putting into practice of new initiatives and as a model of how rationally to approach the uncertainty that besets endeavour of any kind. None of the technological challenges that characterise the end of our millennium could have been addressed without the safety-net that insurance provides. In the social domain, private insurance has come to the rescue of many of the public pension and health structures that were all too hastily established in the aftermath of the last World War.

Insurance, then, in the many and varied guises it has taken on, has recorded steady and uninterrupted growth year on year the world over. Each year, with its choice of "key issues", the Geneva Association has set the tone for a series of cultural events which have become the staging-posts of an intellectually consistent journey: the Annual Lectures, the meetings of the Group of Risk Economists, the quarterly issues of the Geneva Papers, and the General Assemblies of its members. The wise decision taken by its founders at the very outset to create an association of persons rather than of business institutions has fostered the coming together of those ultimately responsible for the main companies at a level which has made possible the promotion of broader interests common to the profession as a whole rather than of competition-driven rivalries.

\footnotetext{
* President of the Geneva Association from 1976 to 1983.
} 
But what achievements exactly has the Association been able to chalk-up during the first quarter century of its existence? Among other things, it has, from its very inception, demonstrated the potential of Risk Management and defined the role the latter was to play. It was able at a very early stage to analyse the advantages and drawbacks of Bank Assurance, and from the 70's onwards, having predicted the coming crisis for social welfare systems, was in a position to propose solutions - from supplementary insurance and part-time work to gradual retirement and the Fourth Pillar. It was able to identify more clearly the shifting frontiers of insurability and helped to familiarise European markets with new kinds of welfare practices like the HMO schemes. In the field of non-life insurance, it did much to foster the adoption of new forms of cover - "Consequential Loss", Third-party products, professional liability of various kinds, and policies covering computer risk, natural catastrophies, and Recall - the list is long. In each of these areas, many of which have become common practice today, the Association, whose vocation is to foresee the future rather than to describe the present, has often been years ahead of the market in showing the way. Overall, it can be said that the Association has secured for insurance issues an indispensable place in contemporary economic thinking thus bringing legislators to a better understanding of the needs of our profession.

May, therefore, the Geneva Association continue to discharge the mission it has set itself and, so doing, continue to confirm a paradox familiar to all men and women of science: that it is fundamental research of a fully independent kind, free of the burden of satisfying any immediate needs, that so often achieves the greatest break-throughs. We, the Association's founding fathers, would wish it every success in that endeavour. 